PRELIMINARY COMMUNICATION

\title{
Effect of freezing rate and storage time on quality parameters of strawberry frozen in modified and home type freezer
}

\author{
Murat Yanat*, Taner Baysal \\ Ege University, Engineering Faculty, Department of Food Engineering, Izmir, Turkey \\ *Corresponding author: muratyanat@gmail.com
}

Abstract

Freezing rate and storage time are the most important parameters in the losses of bioactive compounds of food during the freezing process. For this reason, the quality of strawberries which were frozen at different freezing mediums and the effect of storage time on samples were investigated in this research. The freezer section of the domestic refrigerator was used for slow freezing. Besides that, a modified freezer cabinet which capable of blowing air at a speed of $1.2 \mathrm{~m} / \mathrm{s}$ at $-30^{\circ} \mathrm{C}$ designed and produced by Bosch und Siemens Hausgerate GmbH (Çerkezköy, Turkey) was used for quick freezing. In the quick freezing chamber inside the refrigerator, the samples were provided to be frozen with a higher freezing speed than the static freezing unit of the refrigerator. Freezing time and freezing rates were determined from the cooling curves obtained experimentally. Slow and quick frozen samples were stored at $-25^{\circ} \mathrm{C}$ for 4 months. Drip loss, total phenolic content, ascorbic acid content and total monomeric anthocyanin content of samples were significantly different after freezing and during storage time. It has been determined that higher freezing rate is essential for the better preservation of bioactive compounds of the strawberries. Freezing should be done at an appropriate freezing rate to preserve the cell structure and the nutritional content of strawberries.

Keywords: Drip loss; Freezing; Freezing rate; Frozen Strawberry; Total phenolic content.

\section{Introduction}

Freezing is a simple method of preservation that preserves fruits and vegetables over long periods of time while maintaining many of their fresh-like qualities (Prochaska et al., 2000). However, freezing does not prevent color and texture deterioration, off-flavor development in frozen fruits and vegetables because even at sub-zero temperatures enzyme systems remain active (Rodriguez-Saona et al., 1995). Freezing rate is the most important factor in the freezing process to prevent food tissue damage, loss of bioactive compounds and drip loss in thawing.

Faster freezing results in small ice crystals and a betterfrozen food quality (Alexandre et al., 2013). During freezing, water in the cellular foods is crystallized and converted into ice crystals. Slow freezing normally forms large ice crystals in the extracellular regions of the frozen foods, which may cause damage to food microstructure, resulting in the color, flavor, nutrition and texture modification after thawing, such as tissue softening, increase in drip loss, tissue browning and so on (Sun, 2016).

Foods may be classified into four groups (Poulsen, 1977) according to their sensitivity regarding freezing rate. Products with a high content of dry matter such as peas, high-fat content such as meats, and some ready meals practically unaffected by changes in freezing rate. Fish, lean meat, and starch- and flourthickened ready meals are in the second group where products require a minimum freezing rate $\left(0.5^{\circ} \mathrm{C} / \mathrm{min}\right)$, but relatively unaffected by higher freezing rates. Egg products, many fruits, and vegetables such as strawberry and green bean are classified as products whose quality improves when the freezing rate is increased $\left(3-6^{\circ} \mathrm{C} / \mathrm{min}\right)$. The fourth group is defined by Poulsen (1977) as "products that are sensitive to too high freezing rates and tend to crack". Spies (1979) refined this definition as covering "products in which high freezing rates are advantageous for the product quality, but where temperature tensions in the product result in a destruction of the tissue." For example, fruits and vegetables such as raspberries, tomatoes, and cucumbers.

During the freezing storage of fruits and vegetables, changes occur depending on the storage temperature and the storage period of the products. Fruits and vegetables generally contain bioactive components such as vitamin A and C, phenolics and carotenoids. According to the finding of Chaovanalikit and Wrolstad (2004), there was 50\% loss of total phenolics in cherries for 6 months of storage at $-23^{\circ} \mathrm{C}$. Gonçalves et al., (2011) found that the vitamin $\mathrm{C}$ content of broccoli significantly decreased at storage temperatures of $-7,-15$ and $-25^{\circ} \mathrm{C}$ after 121 days storage. After 90 days of storage, the decrease in the ascorbic acid content of frozen strawberry was $64.5,10.7$ and $8.9 \%$ at $-12,-18$ and $-24{ }^{\circ} \mathrm{C}$, respectively (Sahari et al., 2004).

The aim of the present study were to compare the effects of different freezing rate and storage time on some quality parameters of strawberry samples. 


\section{Materials and methods}

\section{Materials}

Samples of strawberry were obtained from a local market in Izmir region of Turkey. To prepare samples for freezing, they were initially washed in the cold water of $5^{\circ} \mathrm{C}$ and allowed to stand for 15 minutes in ambient conditions to remove the moisture on the surface. Therefore, only medium-sized strawberries which have $3.2 \mathrm{~cm}$ length from top to bottom, with clear red colour, and the suitable degree of ripeness and lack of any apparent damage were selected.

\section{Measurement of the sample temperature and frozen storage}

Slow freezing was achieved in home type freezer at approximately $-18^{\circ} \mathrm{C}$ for 12 hours without air blown. Modified freezer cabinet which designed and produced by Bosch und Siemens Hausgerate GmbH (Çerkezköy, Turkey) was used for quick freezing. This unit situated in the freezer section of home type refrigerator. It capable of blowing air at a speed of $1.2 \mathrm{~m} / \mathrm{s}$ at $-30^{\circ} \mathrm{C}$. This cabin had internal lengths of $18 \times 14 \times 24$ centimeters. In all freezing processes, a $10 \times 5 \times 22 \mathrm{~cm}$ sized, perforated stainless steel container was used. In each freezing process, approximately 400 grams of strawberries were placed in the container. During the entire freezing process, temperature changes occurring in the products and in the freezing environment were monitored by means of T-type thermocouples which were fixed to the center points of the individual samples. Low-density polyethylene (LDPE) bags ( $24 \mathrm{~cm}$ x $28 \mathrm{~cm}$ ) were used for packaging of frozen strawberries. Samples were stored in a domestic freezer at $-25^{\circ} \mathrm{C}$ for 120 days.

\section{Determination of drip loss}

Frozen strawberry samples were thawed at $+4{ }^{\circ} \mathrm{C}$ for 12 hours. The drip loss $\left(\mathrm{d}_{\text {loss }}, \%\right)$ was calculated from equation (1) (Xie \& Zhao, 2014).

$$
\text { drip loss }=\frac{\mathrm{m} 1-\mathrm{m} 2}{\mathrm{~m} 1} \times 100 \%
$$

Where, $m_{1}$ is the mass of the frozen strawberries and $m_{2}$ is the mass of the strawberries after thawing.

Determination of total phenolic content

The total phenolic contents were measured using the Folin-Ciocalteu method (Franke et al., 2004) and expressed as $\mathrm{mg}$ gallic acid $/ \mathrm{kg}$. $5 \mathrm{ml}$ of folin $(10 \%, \mathrm{v} / \mathrm{v})$ and $15 \mathrm{ml}$ of $\mathrm{NaHCO}_{3}(20 \% \mathrm{w} / \mathrm{v})$ are added to $1 \mathrm{~g}$ of pureed and filtered sample. After completing $100 \mathrm{ml}$, the mixture is filtered and after 2 hours in the dark. Absorbance values were recorded at $760 \mathrm{~nm}$ and calculated by taking the concentration-dependent dilutions corresponding to the absorbance from the standard plot. The amount of total phenolic content in the samples was calculated as mg gallic acid equivalents per $1 \mathrm{~kg}$ of dry weight $(\mathrm{mg} / 1 \mathrm{~kg} \mathrm{dw})$.

\section{Determination of ascorbic acid}

The ascorbic acid analysis was performed as applied in the method of Kirca et al. (2007). $10 \mathrm{ml}$ of pureed sample and $90 \mathrm{ml}$ of stabilizer solution were mixed with stirring. In 2 separate test tubes, $1 \mathrm{ml}$ of filtered sample was mixed with $9 \mathrm{ml}$ of purified water and $9 \mathrm{ml}$ of dye solution. Concentration was determined from the standard graph against the absorbance value of the sample and the amount of ascorbic acid in $100 \mathrm{ml}$ was calculated. The amount of ascorbic acid in the samples was calculated as $\mathrm{mg} / 100 \mathrm{~g}$ fresh weight.

Determination of total monomeric anthocyanin content

Total monomeric anthocyanin content was determined by the pH-differential method (Giusti \& Wrolstad, 2001). The samples were diluted in two buffers; $0.025 \mathrm{M}$ potassium chloride $(\mathrm{pH} 1)$ and $0.4 \mathrm{M}$ sodium acetate $(\mathrm{pH} 4.5)$. After $30 \mathrm{~min}$ at $20-22^{\circ} \mathrm{C}$, absorbance at 520 and $700 \mathrm{~nm}$ was measured (Varian Cary 50 spectrophotometer, Scan). The concentration of total monomeric anthocyanin in the samples was calculated as mg cyanidin-3-glucoside equivalents per $1 \mathrm{~kg}$ of dry weight $(\mathrm{mg} / 1 \mathrm{~kg} \mathrm{dw})$.

\section{Statistical analysis}

Results were statistically analyzed by analysis of variance (ANOVA) using the software SPSS 18 (SPSS Inc., Chicago, III, USA) with the Duncan test to evaluate differences between treatments at levels of significance $P<0.05$.

\section{Results and discussion}

\section{Freezing curves and freezing rates}

Cooling curves of samples were shown in Figure 1. Supercooling was detected for both samples as cooling down to a temperature below the freezing point of the sample without formation of ice. When crystal embryos exceed the critical radius for nucleation, systems nucleates at a point lower than freezing point. Then, the temperature increased to the freezing point of samples. The solid content of the fruits and vegetables have the effect on freezing point. Haiying et al., (2007) showed that the existence of many solid particles caused smaller degrees of supercooling in the vegetables. Freezing rates were calculated as $\mathrm{cm} / \mathrm{h}$. The equivalent radius of samples was determined as $1.58 \mathrm{~cm}$ according to the method of Kaya, (2011). Freezing rates from $+4{ }^{\circ} \mathrm{C}$ to $-15{ }^{\circ} \mathrm{C}$ were calculated as 0.32 $\mathrm{cm} / \mathrm{h}$ for home type freezer and $1.50 \mathrm{~cm} / \mathrm{h}$ for the modified quick freezer which are considered slow freezing and quick freezing, respectively.

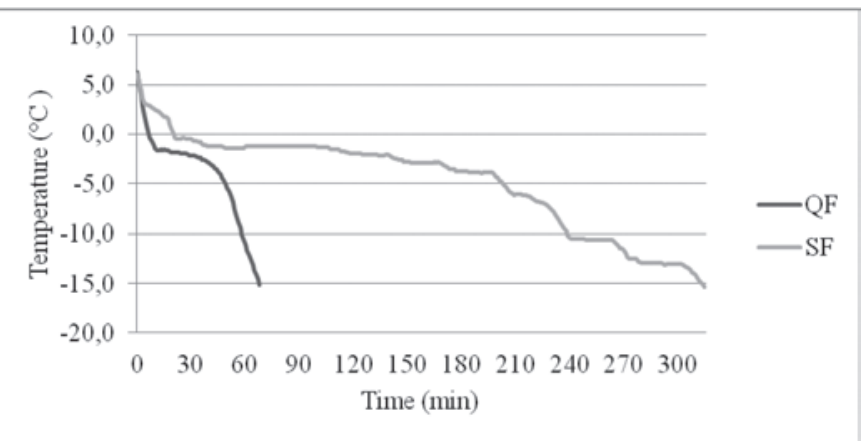

Figure 1. Freezing curves of strawberry samples

\section{Drip loss}

The effect of the different freezing rates and storage time on the drip loss of strawberries after freezing/thawing cycle is shown in Figure 2. The data showed a significantly lower wa- 
ter loss for quickly frozen strawberries when compared to the slowly frozen strawberries during thawing $(\mathrm{P}<0.05)$. In quick frozen strawberry samples, the water removal after thawing is less, indicating that the cell structure of the strawberries was preserved better and that less water released out of the cell, as the freezing rate increases. In a study similar to this, drip loss in frozen strawberry samples was found between $12.75 \%$ and $22.54 \%$ (Çetin \& Fidan, 1984). Therefore, evident increases have observed in the drip loss values of the strawberries after 120 days in storage. Previous studies have also found that losses after thawing of frozen strawberries were affected by freezing rate, cold storage time and storage temperature (Pukszta \& Palich, 2007).

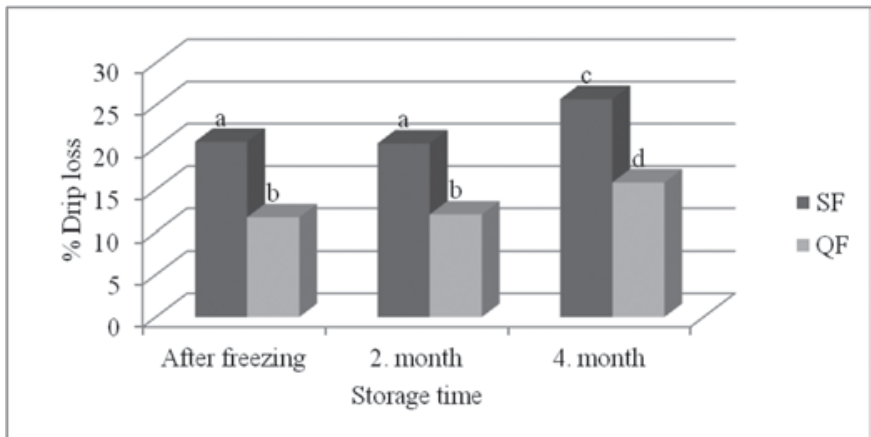

Figure 2. Drip loss values of strawberries

\section{Total phenolic content}

As shown in Figure 3, the effect of freezing rate on phenolic contents of strawberry samples was found statistically significant $(\mathrm{P}<0.05)$ after freezing process and during storage time. Strawberry which is rich in bioactive phenolic substances such as hydroxycinnamic acid, elagic acid, flavanones, and anthocyanins has high antioxidant activity (Määttä-Riihinen et al. , 2004). However, these phenolic compounds are very unstable and undergo destruction during fruits transformation in frozen products especially in the thawing process by native and microbiological enzymes (Garrote \& Bertone, 1989). During the quick freezing process, the loss of phenolic compounds between cells and tissues is lower because cells lose less water and cell structure is less damaged during freezing. In addition, during the thawing process, the loss of phenolic compounds increases with the water moving away from the slow-frozen samples.

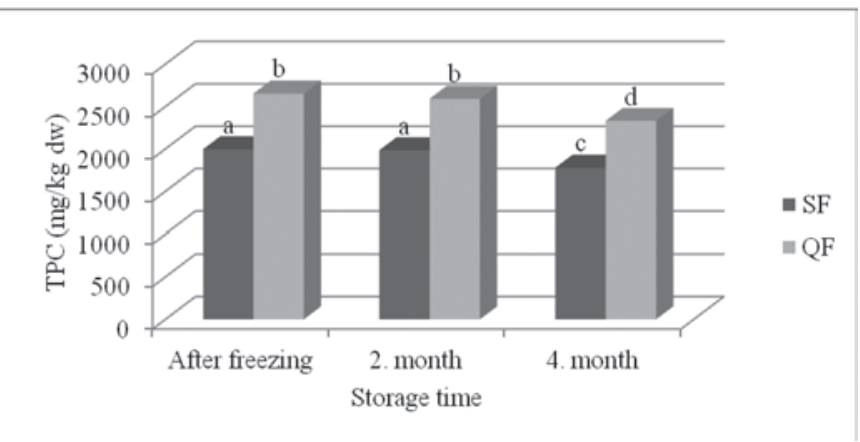

Figure 3. Total phenolic matter content ( $\mathrm{mg} / \mathrm{kg}$ dry basis) of strawberries

\section{Ascorbic acid content}

Strawberries have a relatively high content of vitamin C, which is around $65-84 \mathrm{mg} / 100 \mathrm{~g}$ according to Turkish Food
Composition Database (2014). The ascorbic acid contents of the samples were 56.91, 53.73, $47.47 \mathrm{mg} / 100 \mathrm{~g}$ for slow frozen strawberry samples and 63.11, 63.77, $57.94 \mathrm{mg} / 100 \mathrm{~g}$ for quick frozen strawberry samples after freezing and during the storage, respectively. The difference between the frozen strawberry samples at two different freezing rates was found to be statistically significant $(\mathrm{P}<0.05)$. Vitamin $\mathrm{C}$ can be easily affected by external factors such as temperature, humidity, and light (Favell, 1998). The differences between the ascorbic acid contents are thought to be influenced by the difference in freezing mediums and freezing rates cause different tensile forces on strawberry cells. Therefore, ascorbic acid molecules are separated from the structure along with the water which separates from the strawberry samples during the thawing process. Since more water is separated from slowly frozen samples, loss of ascorbic acid is to be high. After 120 days of storage at $-25^{\circ} \mathrm{C}$, the decrease in the ascorbic acid content of frozen strawberries were found $16.58 \%$ for slow frozen strawberries and $8.19 \%$ for quick frozen strawberries. These results are similar to the findings of Sahari et al. (2004).

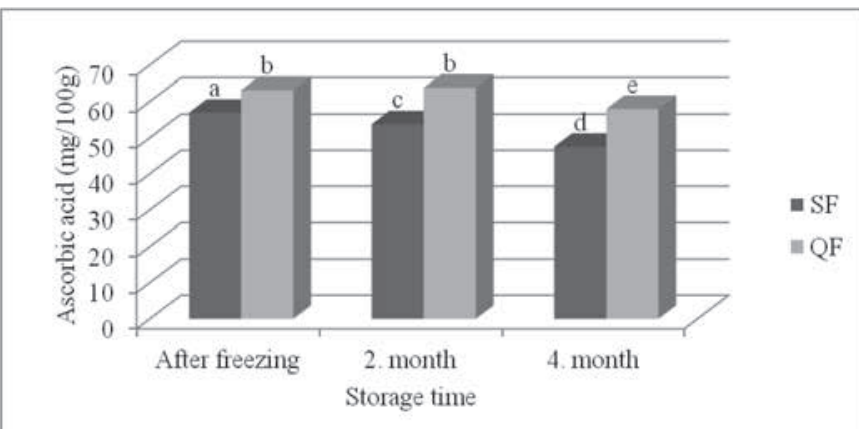

Figure 4. Ascorbic acid content (mg/100g) of strawberries

\section{Total monomeric anthocyanins}

The difference between the amounts of total monomeric anthocyanins between the samples was found to be significant $(\mathrm{P}<0.05)$. The content of monomeric anthocyanin in slowly frozen strawberry samples was lower than that of the quickly frozen sample group. The rate of freezing and the type of freezing technique may also influence the stability of anthocyanins in fruits. Freezing induces the formation of ice crystals, which favors localized concentrations of solutes such as anthocyanins, as well as the reallocation of water molecules in the cell structure. Studies showed that different freezing and thawing procedures have the influence on anthocyanin retention in fruits (Poiana et al., 2010; Holzwarth et al., 2012). In addition, there was a significant reduction in the two sample groups in the total monomeric anthocyanin content at after 4 months in storage. Several studies show a decreasing trend in total fruit anthocyanins during frozen storage in strawberries (Ngo et al., 2007; Garcia-Viguera et al., 1999). 


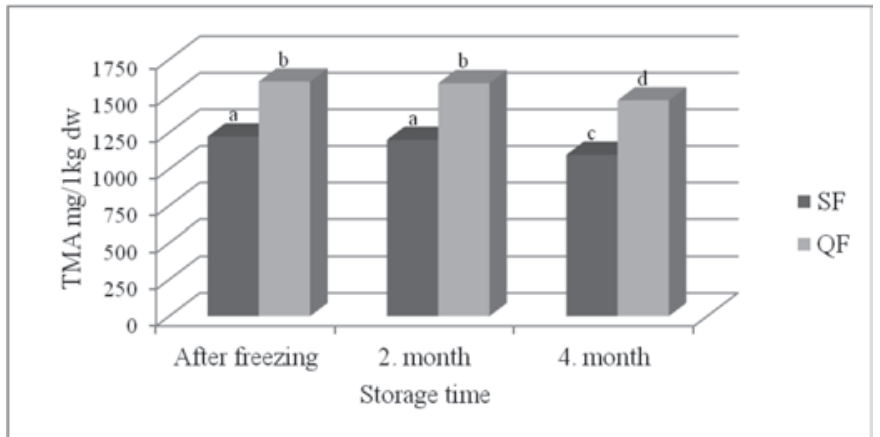

Figure 5. Total monomeric anthocyanin amount of strawberry samples as mg cyanidin-3-glucoside equivalents per $1 \mathrm{~kg}$ dry matter

\section{Conclusions}

Home freezing provided slow freezing rates and freezing in the modified freezer provided quick freezing rates according to this experimental study. It has been observed that ice crystals of different sizes formed in products with different freezing rates have a direct effect on the loss of some important nutrients during the thawing of the samples. During a storage period of 60 days at $-25^{\circ} \mathrm{C}$, slight changes were obtained in the drip loss, total phenolic content, ascorbic acid content and anthocyanin content of samples. Despite that, evident changes have occurred in products after 120 days of storage. Drip losses increased by $24.49 \%$ and $35.18 \%$ in the period between the second and fourth months of storage for the slow and the quick frozen samples, respectively. Besides, approximately $12 \%$ of phenolics were lost for both groups. These situations are thought to be caused by new ice structures resulting from recrystallization. Freezing rate must be the most important parameter for the investigated quality parameters. Freezers that can freeze fruit and vegetable samples at a rate of $1.0 \mathrm{~cm} / \mathrm{h}$ and faster, and store at a colder temperature than $-25^{\circ} \mathrm{C}$, can significantly reduce nutritional compounds loss in these products.

\section{Acknowledgment}

The authors would like to thank Bosch und Siemens Hausgerate $\mathrm{GmbH}$ (Çerkezköy, Turkey) for design and production of modified freezer cabinet, and financial support to this research.

\section{References}

Alexandre E. M. C., Brandao T. R. S., Silva C. L. M. (2013) Frozen food and technology. In: Visakh P. M., Thomas S., Iturriaga L. A., Ribotta P. D. (ed): Advances in Food Science and Technology, Chapter 4. pp. 123-150. Scrivener Publishing LLC, Beverly, USA.

Cetin H., Fidan F. (1984) Cileklerin bazı kalite özellikleri ve derin dondurulmaya uygunluk durumları üzerine araştırma. Gida/The Journal of Food, Cilt 9. Say1 3.

Chaovanalikit A., Wrolstad R. E. (2004) Total anthocyanins and total phenolics of fresh and processed cherries and their antioxidant properties. Journal of Food Science, 67-72.
Favell D. J. (1998) A comparison of the vitamin C content of fresh and frozen vegetables. Food Chemistry, 62 59-64.

Franke S. I. R., Chless K., Silveria J. D., Robensam G. (2004) Study of antioksidant and mutajenic activity of different orange juice. Food Chemistry, 88 45-55.

Garcia-Viguera C., Zafrilla P., Tomas-Barberan, F. A. (1999) Influence of processing and storage conditions in strawberry jam color. Food Science and Technology International, 5 (6) 487-492.

Garrote R. L., Bertone R. A. (1989) Osmotic concentration at low temperature of frozen strawberry halves. Lebensmittel-Wissenschaft und Technologie, 22 264-267.

Giusti R. E., Wrolstad R. E. (2001) Characterization and measurement of anthocyanins by UV-visible spectroscopy. Current Protocols in Food Analytical Chemistry. John Wiley \& Sons Inc., New York. pp. unit F1.2.1-F1.2.13.

Gonçalves E. M., Abreu M., Brandao T. R. S., Silva C. L. M. (2011) Degradation kinetics of color, vitamin C and drip loss in frozen broccoli (Brassica oleracea L. spp. Italica) during storage at isothermal and non-isothermal conditions. International Journal of Refrigeration, 34 2136-2144.

Haiying W., Shaozhi Z., Guangming C. (2007) Experimental study on the freezing characteristics of four kinds of vegetables. LWT Food Science and Technology, 40 1112-1116.

Holzwarth M., Korhummel, S., Carle R., Kammerer D. R. (2012) Evaluation of the effects of different freezing and thawing methods on color, polyphenol and ascorbic acid retention in strawberries (Fragaria $\times$ ananassa Duch.). Food Resource International, 48 241-248.

Kaya C. (2011) Effects of different phosphorus doses on the physico-chemical properties of strawberry during storage. Journal of Food, Agriculture \& Environment, 9 (2) 106-109.

Kirca A., Ozkan M., Cemeroğlu B. (2007) Effects of temperature, solid content and $\mathrm{pH}$ on the stability of black carrot anthocyanins. Food Chemistry, 101 (1) 212-218.

Maatta-Riihinen K. R., Kamal-Eldin A., Törrönen A. R. (2004) Identification and quantification of phenolic compounds in berries of Fragaria and Rubuss species (family Rosaceae). Journal of Agricultural and Food Chemistry, 52 61786187.

Ngo T., Wrolstad, R. E., Zhao Y. (2007) Color quality of Oregon strawberries - impact of genotype, composition, and processing. Journal of Food Science, 72 (1) c25-c32.

Poulsen K. P. (1977) The freezing process under industrial conditions. In: Freezing, Frozen Storage and Freeze Drying Meeting, Karlsruhe, Section 6. pp. 347-353.

Prochaska L. J., Nyugen X. T., Donat N., Piekutowski W. V. (2000) Effects of food processing on the thermodynamic and nutritive value of foods: literature and databese survey. Medical Hypotheses, 54 (2) 254-262.

Pukszta T., Palich P. (2007) The effect of freezing conditions of strawberry storage on the level of thawing drip loss. Acta Agrophsica, 9 (1) 203-208.

Poiana M. A., Moigradean D., Raba D., Alda L. M., Popa, M. (2010) The effect of long-term frozen storage on the nutraceutical compounds, antioxidant properties and color indices of different kinds of berries. Journal of Food, Agriculture \& Environment, 8 (1) 54-58.

Rodriguez-Saona L. E., Barrett D. M., Selivonchick D. P. (1995) Peroxidase and lipoxygenase influence on stability of 
polyunsaturated fatty acids in sweet corn during frozen storage. Journal of Food Science, 60 (5) 1041-1044.

Sahari M. A., Boostani M., Hamidi E. Z. (2004) Effect of low temperature on the ascorbic acid content and quality characteristics of frozen strawberry. Food Chemistry, 86 357-363.

Spies W. (1979) Impact of freezing rates on product quality of deep-frozen foods. In: Food Processing Engineering, $8^{\text {th }}$ European Food Symposium, Espo, Finland. pp. 689-694.

SPSS Inc. (2009) PASW Statistics for Windows, Version 18.0. SPSS Inc, Chicago, USA.

Sun D. W. (2016) Handbook of Frozen Food Processing and Packaging, pp. 303-460. CRC Press, New York, USA.

Anon. (2014) Turkish Food Composition Database. http:// turkomp.gov.tr.

Xie J., Zhao Y. (2014) Use of vacuum impregnation to develop high quality and nutritionally fortified frozen strawberries. Journal of Food Processing and Preservation, 28 117-132. 